\title{
PENANGANAN PERIOPERATIF PADA ASMA
}

\author{
Christina Suhartono \\ Harold F. Tambajong \\ Diana Ch. Lalenoh
}

\author{
Bagian Anestesiologi dan Terapi Intensif Fakultas Kedokteran Universitas Sam Ratulangi \\ Manado
}

\begin{abstract}
The management of a patient with asthma during surgery requires a special treatment based on thorough clinical and laboratory examinations to reduce complications during surgery and the post-operative state. Asthma is characterized by a difficulty in breathing due to spastic contractions of bronchiolar smooth muscles, which partially block the bronchioles' airways. The evaluation of asthma patients before anesthesia and surgical procedures is essential to prevent or control the occurence of asthma attacks during intraoperation and post-operation. Patients with histories of chronic asthma or frequent exacerbations of asthma have to be treated to achieve an optimal condition or a condition in which asthma symptoms are minimal. Patients with frequent bronchospasms should be treated. The selection of drugs and anesthetic procedures should be considered meticulously to avoid a stimulation of bronchospasm or an asthma attack.
\end{abstract}

Keywords: asthma, perioperative management, patient

\begin{abstract}
Abstrak: Pengelolaan pasien dengan penyakit asma selama pembedahan membutuhkan penanganan khusus berdasarkan pemeriksaan klinis dan laboratorium yang saksama untuk mengurangi komplikasi selama dan pasca pembedahan. Asma adalah kesukaran bernapas yang ditandai dengan kontraksi spastik otot polos bronkiolus, yang menyumbat bronkiolus secara parsial. Evaluasi pasien asma sebelum tindakan anestesia dan pembedahan sangat penting untuk mencegah atau mengendalikan kejadian serangan asma, baik selama pembedahan maupun pasca pembedahan. Pasien dengan riwayat asma berulang atau kronis memerlukan pengobatan hingga tercapai kondisi yang optimal untuk dilakukan operasi atau kondisi dimana gejala-gejala asma sudah minimal. Pasien dengan bronkospasme berulang harus diobati terlebih dahulu. Pemilihan obat-obatan dan tindakan anestesia perlu dipertimbangkan dengan cermat untuk menghindari terjadinya bronkospasme atau serangan asma.
\end{abstract}

Kata kunci: asma, penanganan perioperatif, pasien

Pengelolaan pasien dengan penyakit asma selama pembedahan membutuhkan penanganan khusus berdasarkan pemeriksaan klinis dan laboratorium yang saksama untuk mengurangi komplikasi selama dan pasca pembedahan. Masalah paru merupakan penyebab umum morbiditas dan mortalitas selama pembedahan. Komplikasi terjadinya atelektasis atau pneumonia pada pasien dengan fungsi paru normal pada preoperasi hanya 3\%, sedangkan pasien dengan penyakit paru obstruktif kronik yang memiliki perubahan fungsi paru berpeluang mengalami komplikasi sebesar 70\%. Shnider dan Papper serta Gold dan Helrich melaporkan bahwa bronko-spasme yang terjadi selama operasi $\pm 6 \%$ dari pasien asma. ${ }^{1}$

Asma adalah penyakit paru dengan karakteristik sebagai berikut: 1) obstruksi saluran napas yang reversibel, baik secara spontan maupun dengan pengobatan; 2) 
inflamasi saluran napas; 3) peningkatan respon saluran napas terhadap berbagai rangsangan. ${ }^{2,3}$ Penyebab asma dibagi menjadi dua, yaitu asma alergik (ekstrinsik) dan non-alergik (intrinsik). Asma alergik muncul pada masa kanak-kanak, dan mekanisme serangan terjadi melalui reaksi alergi tipe I terhadap alergen. Asma intrinsik dipicu oleh faktor-faktor non-alergen seperti infeksi virus saluran napas, rangsangan iritan, dan olah raga.,

Asma dipengaruhi oleh banyak faktor, antara lain jenis kelamin, usia, status atopi, faktor keturunan, dan faktor lingkungan. Pada masa kanak-kanak ditemukan prevalensi anak laki-laki berbanding anak perempuan 1,5:1, tetapi menjelang dewasa perbandingan tersebut kurang lebih sama, dan pada masa menopause perempuan lebih banyak dari laki-laki. Umumnya prevalensi asma pada anak lebih tinggi dari dewasa, tetapi terdapat juga laporan bahwa prevalensi dewasa lebih tinggi dari anak. Di Indonesia, prevalensi asma berkisar $5-7 \% .^{3}$

Sebelum dilakukan anestesia dan operasi elektif pada pasien dengan riwayat asma terlebih dahulu harus dikontrol keadaan asmanya apakah pasien sedang atau tidak menderita infeksi atau serangan asma. Anestesia konduksi yang dikombinasikan dengan sedatif intravena (diazepam dosis kecil) merupakan pilihan yang lebih baik daripada anestesia saja atau anestesia umum. Asma sedang sampai berat perlu diobati dahulu dengan aminofilin intravena, terbutalin $(0,25 \mathrm{mg})$, atau keduanya. ${ }^{5}$

Pada pasien asma yang memerlukan anestesia umum dan intubasi trakeal harus dipertimbangkan adanya peningkatan resiko terjadinya bronkospasme saat anestesia. Bronkospasme selama pembedahan ditandai dengan wheezing, penurunan volume tidal ekshalasi, atau suatu kenaikan lambat dari gelombang dikapnograf. Penurunan diameter jalan napas yang disebabkan bronkokontriksi yang berat dapat mempengaruhi distribusi gas dalam paru. Hal yang paling penting pada pasien yang dianestesia yaitu meningkatkan konsentrasi gas oksigen inspirasi sampai $100 \%$ pada saat terjadi bronkospasme. Pada akhir pembedahan pasien harus telah bebas wheezing. Obat reverse pelumpuh otot nondepolarisasi dan antikolinesterase tidak akan menimbulkan brokospasme bila diberikan dalam dosis terapeutik yang tepat. Untuk mengurangi resiko terjadinya bronkospasme pada anestesia yaitu dengan menghindari endotracheal tube dan penggunaan anestesia inhalasi. Pemberian bronkodilator melalui nebulator atau sungkup muka pasca pembedahan harus sesegera mungkin.,

\section{FISIOLOGI RESPIRASI}

Paru-paru merupakan organ yang berperan penting dalam proses respirasi dan satu-satunya organ tubuh yang menerima darah dari seluruh curah jantung. Respirasi adalah pertukaran gas-gas antara organisme hidup dan lingkungan sekitarnya. Fungsi utama respirasi ialah pertukaran $\mathrm{O}_{2}$ dan $\mathrm{CO}_{2}$ antara darah dan udara pernapasan, sedangkan fungsi tambahan ialah pengendalian keseimbangan asam basa, metabolisme hormon, dan pembuangan partikelpartikel asing. ${ }^{8}$

Pada manusia dikenal dua macam respirasi yaitu eksternal dan internal. Respirasi eksternal ialah pertukaran gas-gas antara darah dan udara sekitarnya. Pertukaran ini meliputi beberapa proses yaitu: ventilasi, distribusi, difusi, dan perfusi. Respirasi internal ialah pertukaran gas-gas antara darah dan jaringan. Pertukaran ini juga meliputi beberapa proses yaitu: efisiensi kardiosirkulasi dalam menjalankan darah kaya oksigen, distribusi kapiler, difusi gas-gas, dan metabolisme sel. ${ }^{8,9}$

\section{PENGARUH ANESTESIA PADA RES- PIRASI}

Efek penekanan dari obat anestetik dan pelumpuh otot lurik terhadap respirasi telah dikenal sejak dahulu ketika kedalaman, karakter, dan kecepatan respirasi diterima sebagai tanda klinis yang bermanfaat terhadap kedalaman anestesia. ${ }^{8}$ Zat-zat anestetik intravena dan bersifat abar (volatil) serta golongan opioid menekan pernapasan dan menurunkan respons terhadap $\mathrm{CO}_{2}$. 
Respons ini tidak seragam; golongan opioid mengurangi laju pernapasan sedangkan zat abar trikloretilen meningkatkan laju pernapasan. Hiperkapnia atau hiperkarbia (tekanan parsial karbon dioksida dalam darah arteri, $\mathrm{PaCO}_{2}$ meningkat) akan merangsang kemo-reseptor di badan aorta dan karotis kemudian diteruskan ke pusat napas sehingga terjadi pernapasan dalam dan cepat (hiperventilasi). Sebaliknya, hipokapnia atau hipokarbia $\left(\mathrm{PaCO}_{2}\right.$ menurun) akan menghambat kemoreseptor di badan aorta dan karotis kemudian diteruskan ke pusat napas sehingga terjadi napas dangkal dan lambat (hipoventilasi). ${ }^{8}$

Induksi anestesia akan menurunkan kapasitas sisa fungsional (Functional Recidual Volume, FRC), mungkin akibat pergeseran diafragma ke atas pada pemberian pelumpuh otot. ${ }^{8}$ Pada perokok berat lapisan mukosa jalan napas mudah terangsang, produksi lendir meningkat, kandungan $\mathrm{HbCO}$ darah sampai kira-kira $10 \%$, dan kemampuan $\mathrm{Hb}$ mengikat $\mathrm{O}_{2}$ menurun sampai $25 \%$. Nikotin akan menyebabkan takikardia dan hipertensi. ${ }^{8}$

\section{ASMA}

\section{Definisi asma}

Asma adalah kesukaran bernapas yang ditandai dengan kontraksi spastik otot polos bronkiolus yang menyumbat bronkiolus secara parsial. Para ahli berpendapat bahwa asma ialah penyakit paru dengan karakteristik adanya obstruksi saluran napas yang reversibel (tetapi pemulihan bisa tidak lengkap pada beberapa pasien) baik secara spontan maupun dengan pengobatan. Inflamasi saluran napas terjadi akibat peningkatan respons saluran napas terhadap berbagai rangsangan (hiper-reaktivitas). ${ }^{3,10}$

Asma dibedakan atas dua jenis, asma alergik dan asma non-alergik. Asma alergik muncul pada masa kanak-kanak; mekanisme terjadinya serangan melalui reaksi alergi tipe I terhadap alergen. Asma nonalergik atau intrinsik tidak memperlihatkan adanya tanda-tanda reaksi hipersensitivitas terhadap alergen. ${ }^{3}$ Baik pada asma alergik maupun non-alergik terjadi inflamasi dan hipereaktivitas saluran napas. Terdapat dua jalur yang berperan untuk terjadinya kedua hal tersebut, yaitu jalur imunologik (terutama didominasi oleh $\mathrm{IgE}$ ) dan jalur saraf autonom. ${ }^{3,11}$ Pasien dengan asma berisiko tinggi untuk mengalami komplikasi perioperatif sehingga berpeluang terjadi peningkatan morbiditas. $4,5,9$

\section{Patofisiologi asma}

Obstruksi saluran napas pada asma merupakan kombinasi spasme otot bronkus, sumbatan mukus, edema, dan inflamasi dinding bronkiolus. Obstruksi bertambah berat selama ekspirasi karena secara fisiologik saluran napas menyempit pada fase tersebut. Hal ini mengakibatkan udara distal tempat terjadinya obstruksi terjebak dan tidak dapat diekspirasi. Pada jalan napas terjadi peningkatan sel-sel inflamasi terutama eosinofil, sel mast, dan limfosit Th CD4. Elastic recoil paru berkurang bersama-sama dengan aktifitas persisten dari otot inspirasi dan ekspirasi. Tekanan alveolar tetap positif hingga akhir ekspirasi; fenomena ini dikenal sebagai tekanan akhir ekspirasi positif intrinsik/auto (intrinsic/ auto Positive End Expiration Pressure, PEEP), yang dapat menyebabkan kompresi dinamik dari jalan napas distal. Frekuensi ekspirasi paksa (Forced Expiration Volume, FEV) dan kapasitas vital (Vital Capacity, VC) berkurang. Terperangkapnya udara menyebabkan peningkatan Functional Recidual Capacity (FRC) sehingga kapasitas paru total dan usaha pernapasan meningkat. Hiperinflamasi memperburuk fungsi otototot respiratorik. Resistensi vaskular paru meningkat, dan curah jantung menurun. Hal ini akan memburuk bila pasien mengalami hipovolemik. ${ }^{3}$

\section{PENANGANAN DAN PENGELOLA- AN PERIOPERATIF}

\section{Penanganan pasien asma preoperatif}

Tujuan penanganan preoperatif pasien dengan asma yaitu untuk memaksimalkan fungsi paru pasien tersebut. Pasien disaran- 
kan berhenti merokok dua bulan sebelum pembedahan. Evaluasi pasien asma sebelum tindakan anestesia dan pembedahan sangat penting untuk mencegah ataupun mengendalikan kejadian serangan asma, baik saat intraoperatif maupun pascaoperatif. Evaluasi yang dilakukan meliputi riwayat penyakit, pemeriksaan fisik, pemeriksaan laboratorik, pemeriksaan fungsi paru dan analisis gas darah, dan foto toraks. ${ }^{11-13}$ Hasil evaluasi akan dipakai untuk menentukan status fisik pra-anestesia. The American Society of Anesthesiologists (ASA) menyusun klasifikasi status fisik pra-anestesia atas enam kelas, yaitu: ${ }^{11}$

ASA 1: pasien penyakit bedah tanpa disertai penyakit sistemik.

ASA 2: pasien penyakit bedah disertai dengan penyakit sistemik ringan sampai sedang.

ASA 3: pasien penyakit bedah disertai dengan penyakit sistemik berat yang disebabkan karena berbagai penyebab tetapi tidak mengancam nyawa.

ASA 4: pasien penyakit bedah disertai dengan penyakit sistemik berat yang secara langsung dapat mengancam kehidupannya.

ASA 5: pasien penyakit bedah yang disertai dengan penyakit sistemik berat yang sudah tidak mungkin ditolong lagi, dioperasi ataupun tidak dalam 24 jam pasien akan meninggal.

ASA 6: pasien yang telah dinyatakan mati otak, organnya dikeluarkan untuk keperluan donor tetapi harus atas ijin pasien atau keluarga.

Pada pengelolaan preoperatif pasien dengan asma, sebagai langkah pertama yaitu menentukan reversibilitas kelainan. Proses obstruksi yang revesibel ialah bronkospasme, sekret yang terkumpul, dan proses inflamasi jalan napas. Pasien dengan bronkospasme yang sering harus diobati dengan preparat bronkodilator, teofilin, dan kortikosteroid. $^{3}$

\section{Terapi farmakologik}

Obat-obat yang digunakan pada pena- nganan asma yaitu golongan simpatomimetik, antagonis leukotrien, steroid, dan antiimmunoglobulin E (anti-IgE). Obat-obat lain yang jarang digunakan ialah golongan mukolitik, mast cell stabilizers, dan golongan parasimpatolitik. ${ }^{12}$

\section{Golongan simpatomimetik ( $\beta$ adrenergik dan epinefrin)}

Pasien dengan riwayat asma atau yang diketahui pernah mengalami wheezing preoperatif perlu diberikan golongan $\beta$ adrenergik. Short-acting $\beta$ adrenergik secara rutin digunakan pada eksaserbasi asma untuk menghilangkan gejala-gejala dengan segera. Golongan simpatomimetik menyebabkan dilatasi bronkiolus melalui aktivasi adenylate cyclase dan peningkatan cyclic adenosine monophosphate (cAMP) yang memediasi relaksasi otot polos bronkiolus. Obat-obat ini juga menghambat pelepasan anti-histamin dan neurotransmiter kolinergik. $\beta$-adrenergik selektif umumnya diberikan secara inhalasi (metered dosed inhaler, MDI) dan sampai saat ini merupakan preparat yang paling efektif. Sebagai contoh, salbutamol, salmeterol, metaproterenol, dan terbutalin sulfat. Pasien yang menggunakan $\beta$-blocker hendaknya yang tidak menimbulkan spasme bronkiolus seperti atenolol, atsumetropolol, atau esmolol. $\beta 1$ dan $\beta 2$ adrenergik non-selektif termasuk epinefrin (adrenalin), isoproterenol dan isoetharin berefek takikardi dan aritmogenik sehingga dapat membahayakan pasien penyakit jantung. ${ }^{3,12}$

\section{Golongan santin (teofilin)}

Efek teofilin sama dengan golongan simpatomimetik, tetapi mempunyai cara kerja berbeda sehingga bila kedua obat ini dikombinasikan efeknya saling memperkuat. Sebagai bronkodilator, teofilin bekerja melalui dua mekanisme di paru yaitu relaksasi otot polos dan menekan rangsangan stimuli jalan napas. Mekanisme kerja yang pasti belum diketahui, diduga efek bronkodilatasi disebabkan oleh adanya penghambatan isoenzim phosphodiesterase PDE III dan PDE IV. Efek teofilin lainnya 
berhubungan dengan aktivitas molekular yang lain. Teofilin juga dapat meningkatkan kontraksi otot diafragma dengan cara peningkatan uptake $\mathrm{Ca}$ melalui adenosin-mediated channels. Pada serangan asma yang akut dan berat yang berhubungan dengan bronkitis kronis dan enfisema digunakan aminofilin. Aminofilin merupakan kompleks 2:1 dari teofilin dan etilendiamin. Teofilin sebagai bahan untuk antiasma sedangkan etilendiamin digunakan untuk membentuk kompleks aminofilin yang mudah larut dalam air. Pengunaan aminofilin tidak dianjurkan pada anak berusia $<12$ tahun. Berbagai jenis obat-obatan dapat meningkatkan kadar teofilin, yang perlu dipertimbangkan pada saat preanestesia. $^{11}$

\section{Kortikosteroid}

Obat golongan ini sering digunakan pada pasien yang tidak berespon terhadap pemberian antagonis $\beta 2$ adrenergik. Pada serangan asma berat digunakan kortikosteroid parenteral. Kortikosteroid sistemik digunakan untuk mengontrol eksaserbasi berat, mencegah progresivitas dan inflamasi, pemulihan yang cepat, dan mengurangi tingkat kekambuhan. Mekanisme kerja obat ini melalui pengurangan edema mukosa dan stabilisasi membran sel mast. ${ }^{4,11,12}$

\section{Golongan antikolinergik}

Salah satu obat golongan ini ialah ipratropium bromide yang digunakan untuk menghilangkan bronkospasme akut. Golongan ini menyebabkan bronkodilatasi melalui inhibisi kompetitif pada reseptor kolinergik muskarinik dan menurunkan tonus vagal jalan napas. Selain itu, golongan ini menghambat refleks bronkokonstriksi terhadap iritan atau terhadap reflux esophagitis dan dapat menurunkan sekresi kelenjar mukus. Antikolinergik merupakan terapi pilihan untuk bronkospasme akibat kerja $\beta$ blocker. ${ }^{11}$

\section{Immunoterapi anti-IgE}

Golongan ini merupakan penanganan terbaru untuk asma berat. Omalizumab terdiri dari recombinant humanized $\operatorname{IgG}$ monoclonal anti-IgE antibody yang akan terikat pada IgE (molekul yang berperan dalam patofisiologi asma alergik). Omalizumab yang terikat pada IgE secara elektif mengeluarkannya dari sirkulasi, sehingga menurunkan inflamasi. Omalizumab umumnya digunakan pada moderate persistent asthma dan asma berat. ${ }^{11}$

\section{Penanganan pasien asma intraoperatif}

Analgesia atau anestesia regional adalah tindakan analgesia yang dilakukan dengan cara menyuntikkan obat anestetika lokal pada lokasi serat saraf yang menyarafi regio tertentu, yang menyebabkan hambatan konduksi impuls aferen yang bersifat temporer. ${ }^{1,4,11}$ Jenis-jenis analgesia regional yaitu blok saraf, blok pleksus brakhialis, blok spinal sub arakhonoid,' blok spinal epidural, dan blok regional intravena. ${ }^{1}$ Pilihan teknik bisa anestesia regional dimana pasien tetap sadar dan mengontrol pernapasannya sendiri, sedangkan pada situasi lain diperlukan kombinasi anestesia umum dan regional dengan pertimbangan pengendalian nyeri pasca-operatif. Bila memungkinkan, dipilih anestesia regional dengan blok rendah dan continuous epidural dengan lidocaine $1,5 \mathrm{mg} / \mathrm{kg}$ (hanya analgesia) sehingga otot-otot pernapasan tidak terganggu.

Pada keadaan yang memerlukan anaestesia umum, diberikan premedikasi dengan antihistamin seperti prometazin bersama hidrokortison $100 \mathrm{mg}$. Tujuan anestesia umum yaitu smooth induction dan kedalaman anestesia disesuaikan dengan stimulasi. ${ }^{6,9,10,12,13}$ Laringoskopi dan intubasi dihindari pada anestesia yang dangkal karena dapat menyebabkan bronkospasme. Peningkatan suara napas oleh stimulasi vagal disebabkan oleh endoskopi, dan peritoneal atau visceral stretch. Ketamin cukup baik untuk induksi intravena karena bersifat bronkodilator. Untuk tindakan singkat, sebaiknya digunakan teknik masker wajah setelah induksi dengan menghindari intubasi. Oksigen digunakan dengan konsentrasi $30 \%$ atau lebih untuk 
udara inspirasi. ${ }^{4}$ Bila dibutuhkan intubasi, anestesi harus ditambah dalam dengan inhalasi, kemudian dilakukan intubasi tanpa relaksan otot. Pada pasien yang dianestesia dalam dapat dilakukan laringoskopi tanpa menyebabkan bronkospasme bila diintubasi. Cisatracurium tidak menyebabkan pelepasan histamin atau bronkospasme sedangkan rocuronium dapat digunakan untuk pasien asma yang memerlukan intubasi cepat. Eter dan halotan merupakan bronkodilator yang baik. Eter mempunyai kelebihan bila terjadi bronkospasme. Pemakaian epinefrin $0,5 \mathrm{mg}$ subkutan bisa diberikan dengan aman, namun hal ini berbahaya bila diberikan bersamaan dengan halotan atau trikloretilen karena dapat menyebabkan gangguan irama jantung akibat efek katekolamin. Sebagai alternatif pengganti epinefrin, dapat diberikan aminofilin $250 \mathrm{mg}$ intravena secara lambat untuk dewasa karena obat ini cocok dengan semua obat inhalasi. Pada akhir tindakan bila memakai intubasi, ekstubasi dilakukan dalam posisi miring dan dengan anestesia dalam, karena stimulasi laring dapat memicu bronkospasme. ${ }^{1,2,5,9,12,13}$

\section{Penanganan pasien asma pasca-operatif}

Pemberian bronkodilator dilanjutkan sesegera mungkin pada pasca-operatif melalui nebulator atau sungkup muka hingga pasien mampu menggunakan MDI sendiri secara benar. ${ }^{8}$ Kategori pasien yang memperoleh manfaat terapi MDI bila memenuhi kriteria sebagai berikut: frekuensi pernapasan $<25 \mathrm{kali} /$ menit, mampu menahan napas selama 5 detik atau lebih, kapasitas vital $>15 \mathrm{ml} / \mathrm{kg} \mathrm{BB}$, mampu berkomunikasi verbal dan mengikuti instruksi, koordinasi tangan-mulut, inspirasi memadai, PEFR $\geq 150 \mathrm{~L} /$ menit untuk perempuan dan $>200$ L/menit untuk laki-laki. Pada akhir pembedahan pasien harus bebas wheezing. Reversal pemblok neuromuskular nondepolarising dengan antikolinesterase tidak menimbulkan bronkospasme bila diberikan dosis antikolinergik yang tepat. Obstruksi jalan napas, laringospasme, bronkospasme, ventilasi yang rendah, dan hipoksemia merupakan ancaman utama. Pasien yang teridentifikasi berisiko tinggi perlu dimasukkan ke unit monitoring pasca-operatif agar fisioterapi dada dan suction dapat dilakukan. Penanganan nyeri pasca-operatif perlu diatasi untuk menurunkan kejadian bronkospasme. Parameter respirasi yang harus dinilai pasca-anestesia yaitu suara napas paru harus sama di kedua paru, frekuensi napas 10-35 x/menit, irama napas teratur, volume tidal minimal $4-5 \mathrm{ml} / \mathrm{kg}$ $\mathrm{BB}$, kapasitas vital $20-40 \mathrm{ml} / \mathrm{kg} \mathrm{BB}$, inspirasi paksa $-40 \mathrm{~cm} \mathrm{H}_{2} \mathrm{O}, \mathrm{PaO}_{2}$ pada $\mathrm{FiO}_{2} 30 \% 100 \mathrm{~mm} \mathrm{Hg}$, dan $\mathrm{PaCO}_{2}$ 30-45 mm Hg. ${ }^{1,2,5,9,12,13}$

\section{SIMPULAN}

Evaluasi pasien asma sebelum tindakan anestesia dan pembedahan sangat penting untuk mencegah atau mengendalikan kejadian serangan asma, baik intraoperatif maupun pasca-operatif, yang meliputi anamnesis serta pemeriksaan fisik, laboratorik, radiologik, analisis gas darah, dan tes fungsi paru-paru. Pasien dengan riwayat asma frekuen atau kronis perlu dilakukan pengobatan sampai tercapai kondisi yang optimal untuk dilakukan operasi atau kondisi dimana gejala-gejala asma sudah minimal. Pasien dengan bronkospasme yang frekuen harus diobati dengan preparat bronkodilator, dosis terapi teofilin, dan kortikosteroid. Pemilihan obat-obatan dan tindakan anestesia perlu dipertimbangkan secara cermat untuk menghindari penggunaan obat-obatan dan tindakan yang merangsang terjadinya bronkospasme atau serangan asma. Persiapan tindakan dan obatobat untuk mengatasi serangan asma atau bronkospasme sejak saat pra-anestesi agar jika terjadi serangan bronkospasme kondisi reversibel dapat tercapai.

\section{DAFTAR PUSTAKA}

1. Warner DO, Warner MA, Barnes RD, Offord KP, Schroeder DR, Gray DT, et al. Perioperative respiratory complications in patients with asthma. Anesthesiology. 1996;85:459-67. 
2. Bishop MJ, Cheney FW. Anesthesia for patients with asthma, low risk but not no risk. Anesthesiology. 1996;85:455-6.

3. Sundaru H, Sukamto. Asma bronkial. In: Sudoyo AW, Setyohadi B, Alwi I, Simadibrata MK, Setiati S. Buku Ajar Ilmu Penyakit Dalam (Edisi V). Jakarta: Interna Publishing, 2009; p. 404-8.

4. Dewachter $P$, Mouton-Faivre $C$, Emala CW, Beloucif S. Case Scenario: Bronchospasm during anesthetic induction. Anesthesiology. 2011;114(5):1200-10.

5. Euliano TY, Gravenstein JS. Pre-operative evaluation. In: Essential Anesthesia from Science to Practice. Cambridge: University Press, 2004.

6. Latief SA, Suryadi KA, Dachlan MR. Petunjuk Praktis (Edisi Kedua). Jakarta: FKUI, 2010.

7. Searl CP. Respiratory physiology. In: Searl CP, Ahmed ST, editors. Core Topics in Thoracic Anesthesia. Cambridge: Cambridge University Press, 2009; p.9-14.

8. Guyton AC, Hall JE. Guyton \& Hall Buku Ajar Fisiologi Kedokteran (Edisi 11). Jakarta: EGC, 2007.
9. Pyrgos G, Brown R. Should patients with asthma be given perioperative medications including steroids? In: Lee A. Fleisher, editor. Evidence-based Practice of Anesthesiology (Second Edition). Philadelphia: Saunders Elsevier, 2009. p. 60-3.

10. Searl CP. Respiratory diseases. In: Searl CP, Ahmed ST, editors. Core Topics in Thoracic Anesthesia. Cambridge: Cambridge University Press, 2009; p.25-26.

11. Mangku G, Senapathi TGA. Tatalaksana Anestesia dan Reanimasi Buku Ajar Ilmu Anestesia dan Reanimasi. Jakarta: Indeks, 2010.

12. Horvath G, Wanner A. Bronchial arterial circulation in the human. In: Yuan JXJ, Hales CA, Archer SL, Garcia JGN, Rich S, West JB. Textbook of Pulmonary Vascular Disease. New York: Springer, 2010; p.447.

13. McKenna SS. Obstructive and restrictive lung disease. In: Rosenblatt WH, Aglio LS, Allen PD, Bader AM, Beutler SS, Camann WR, et al. Essential Clinical Anesthesia. Cambridge: Cambridge University Press, 2011; p.20-21. 